\title{
Influence of aestivation on the survival of Galba truncatula (Mollusca : Gasteropoda) populations according to altitude
}

\author{
M.D. Goumghar ${ }^{1,2}$ \\ D. Rondelaud ${ }^{2}$ \\ G. Dreyfuss ${ }^{2}$ \\ M. Benlemlih ${ }^{1}$
}

Keywords : Galba truncatula, aestivation, altitude, Massif Central.

Field and laboratory studies on 11 populations of Galba truncatula were performed to determine the survival rate of snails after aestivation, to specify the range of their shell heights, and to establish the percentage of $G$. truncatula which burrowed in soil when summer drying occurred. These investigations were performed using six lowland populations living in central France (alt. 206-282 m) and five highland populations, located in the Massif central (alt. 806-900 m). The survival rate of G. truncatu$l a$ after flooding dried soil with water was significantly higher in the highland than in the lowland populations (69.5-80.7\% in road ditches, for example, instead of 29.3-33.0\%). The mean shell heights of surviving snails and the durations of snail re-activation in water did not show any significant variation, whatever the origin of snail population. The percentages of snails buried in drying soil were higher in the highland population $(13.0 \%$ and $15.0 \%$ of juvenile snails, for example, instead of $4.0 \%$ and $7.7 \%$ in lowland snails). In the lowland population only young snails buried, whereas 5.8-8.3\% of adults in the highland population were partially burrowing. The local climate of the sites studied in the Massif central, and the ability of snails to burrow into the mud when stagnant water disappeared in July, might explain the higher survival rate during aestivation.

\section{Influence de l'estivation sur la survie de populations de Galba truncatula Müller (Mollusca : Gasteropoda) en fonction} de l'altitude

Mots-clés : Galba truncatula, altitude, estivation, Massif Central.

Des études sur le terrain et au laboratoire sur 11 populations de Galba truncatula vivant en plaine ou en altitude ont été réalisées pour déterminer le taux de survie des mollusques après l'estivation, préciser la gamme de leurs hauteurs de coquilles et établir le pourcentage de $G$. truncatula qui s'enterrent dans le sol lors de l'assèchement estival. Ces observations ont été effectuées en utilisant six populations de plaine, vivant dans le centre de la France (alt. 206-282 m) et cinq colonies d'altitude, situées dans le Massif central (alt. 806-900 m). La survie des limnées après l'inondation du sol desséché est significativement plus élevée dans les populations d'altitude que dans celles de plaine (69,5 à $80,7 \%$ dans les'fossés de route, par exemple, au lieu de 29,3 à $33 \%$ ). La hauteur moyenne des coquilles des mollusques survivants et la durée de leur reprise d'activité dans l'eau ne présentent pas de variation significative, quelle que soit l'origine des mollusques. Les pourcentages de limnées enterrées dans le sol en dessèchement sont plus élevés en altitude ( 13 et $15 \%$ des juvéniles, par exemple, au lieu de 4 et $7,7 \%$ en plaine). Chez ces dernières populations, seuls les jeunes mollusques s'enterrent alors que 5,8 et 8,3\% des adultes en altitude s'enfouissent partiellement. Le climat local des sites étudiés et l'aptitude des mollusques à s'enterrer dans le sol avant la disparition de l'eau stagnante en juillet peuvent expliquer la survie plus élevée des limnées pendant l'estivation. 


\section{Introduction}

The snail Galba truncatula O.F. Müller is capable of survival throughout a considerable period of drought, i.e. more than a year under laboratory conditions (Kendall 1949). In the field, the aestivation of this species decreases in length with increasing altitude, as it ranges between 4 and 8 weeks in central France below $300 \mathrm{~m}$ (Rondelaud \& Morel-Vareille 1975), between 3 and 6 weeks in the Jura at $800-1,200 \mathrm{~m}$, and does not exist in the Alps between 1,800 and 2,600 m (de Massias et al. 1996). Consequently, the number of snails surviving after aestivation is higher in the highland than in the lowland areas : it was less than $20 \%$ in the habitats of $G$. truncatula below $300 \mathrm{~m}$ in altitude (Rondelaud \& Morel-Vareille 1975) and increased up to $55 \%$ in those located at $800-1,200 \mathrm{~m}$ (de Massias 1995).

Several authors, such as Mehl (1932), Peters (1938), Roberts (1950), Bednarz (1960), Rondelaud \& Morel-. Vareille (1975), or Smith (1981), for example, have already reported that the newborns and the juvenile $G$. truncatula from the lowland populations were more resistant to summer drought than older snails. However, as the conditions of aestivation in these populations depended on seasonal climatic variations which occurred in snail habitats, several differences could be noted. In central England, for example, many snails survived with the aperture attached to the mud surface (Kendall 1949), whereas in several sites of central France (alt. $<300 \mathrm{~m}$ ), the alive snails were few in number and numerous empty shells were found on the surface of the soil or in the upper zone of soil cracks (Rondelaud \& Morel-Vareille 1975). By contrast, little information is available on the aestivation of $G$. truncatula in the highland habitats. In the Massif Central (alt. $820 \mathrm{~m}$ ), a few empty shells on the soil surface were found after a 4-week summer drying of the habitat and there was only a decrease by $50 \%$ in the number of surviving snails when the area was covered with water again (unpubl. data). To explain these differences, the following questions have arisen : has the altitude of sites and, consequently, local climatic conditions, an influence on the ability of $G$. truncatula to aestivate ? Do the shell heights of surviving snails show any fluctuations in relation to altitude ? Do the snails from lowland or highland populations aestivate by burrowing into the substratum ? To answer these questions, three experiments were carried out in the field and the laboratory on 11 French populations of $G$. truncatula, living in highland and lowland stations.

\section{Material and methods}

\subsection{Snails studied}

The six lowland populations of G. truncatula are living in the department of Haute-Vienne (central France) and inhabit peripheral extremities of open drainage furrows in swampy meadows (4 sites) or road ditches (2 sites). All these habitats are located within a $10 \mathrm{~km}$ radius around the town of Bellac and their altitude ranges from 206 to $282 \mathrm{~m}$. The five highland populations are located in the department of Puy-de-Dôme (in the Massif Central) and also colonize open drainage furrows in meadows (3 sites) or road ditches ( 2 sites). These last stations are located in the communes of Bromont Lamothe, Pontgibaud, and Saint-Ours, and their altitude ranges from 806 to $900 \mathrm{~m}$. The geographic distance between the former stations and the latter sites is $160 \mathrm{~km}$.

The subsoil comprises metamorphic rocks. The lowland stations have underlying two-mica granites or migmatites, whereas the substratum of highland sites is constituted with augen gneiss. Water is running in the ditches from the beginning of October to mid-July, and summer drying of habitats occurs from the end of July to the end of August, so that its length is similar in the four stations (6 weeks in 1996, 5 in 1997, and 6 in 1998). Water is oligocalcic, with a pH ranging from 6.5 to 6.7 , an electric conductivity from 55.0 to 70.5 $\mu \mathrm{S} / \mathrm{cm}$, a calcium ion content from 9.7 to $15.5 \mathrm{mg} / \mathrm{l}$ and a nitrate content from 0.1 to $1.1 \mathrm{mg} / 1$ (Goumghar 2000). In the 11 sites, the maximum shell height of adult snails scarcely reaches $8 \mathrm{~mm}$.

The climate is continental, but it is more under oceanic influence in the department of Haute-Vienne than in the Massif central. Average annual rainfall was $850 \mathrm{~mm}$ in the lowland stations, and $1039 \mathrm{~mm}$ in the highland sites. However, in the four stations, the monthly rainfall during the investigations in the field was close in the four sites $(28,33$, and $31 \mathrm{~mm}$ in the lowland sites in July 1996, July 1997, and July 1998, respectively, and 32,35 , and $35 \mathrm{~mm}$ in the corresponding highland sites for the same periods) (Goumghar 2000).

\subsection{Protocol of experiments}

The first investigation was performed in 1996 in seven habitats of $G$. truncatula, located at the peripheral extremities of open drainage furrows. However, as the mean area of these snail habitats was less than $5 \mathrm{~m}^{2}$ in swampy meadows (Vareille-Morel et al. 1999), the experiment was replicated in 1997 and 1998 in four road ditches each colonized by an abundant population of 
snails. Every year, one, two, or five $2 \mathrm{~m}^{2}$ areas were chosen in each site for their high numbers of snails (more than 40 snails per area) (Table 1). Each area selected was individually isolated from the rest of the ditch by the construction of two $25 \mathrm{~cm}$ high dykes with packed mud and stones. A first count of live snails was performed at mid-June when each area was still covered with a $5 \mathrm{~cm}$ layer of water. The live snails and empty shells present on mud were again counted and removed from every area when the soil started to crack (at the onset of July). When the first crack in the soil was $1 \mathrm{~cm}$ wide, six hundred litres of spring water were gradually poured in each area for six hours to flood dried substratum and to re-activate aestivating snails. A third count of surviving snails was performed two days after the flooding of each area and their shell heights were measured using a calliper rule.

The second investigation was performed in 1997 and 1998 under laboratory conditions to verify the results of the first experiment. Six, eight, or ten samples of soil (surface of each sample : $1 \mathrm{dm}^{2}$, soil thickness : 3-4 cm, weight: $100-150 \mathrm{~g}$ ) were collected in three lowland and three highland habitats when the soil cracks were $0.7-1.3 \mathrm{~cm}$ wide (Table 2). Each sample of dried soil was then placed in a $10 \mathrm{~cm}$ deep layer of spring water. All trials were performed in a room subjected to temperatures diurnally fluctuating from $6^{\circ} \mathrm{C}$ to $22^{\circ} \mathrm{C}$. Soil samples were kept under constant surveillance to determine the duration of each snail re-activation after placing in water, to count live snails, and to measure their shell height with a calliper rule.

The third investigation was performed in 1998 under laboratory conditions and repeated in 1999 to determine the percentage of $G$. truncatula that burrowed in soil during an experimental drying. A lowland and a highland population of snails were used in this experiment. Every year, a total of 200 juvenile snails (1-2 $\mathrm{mm}$ in height) and 120 adults $(4-6 \mathrm{~mm})$ were collected at mid-June from each population. Breeding boxes of $0.66 \mathrm{~m}^{2}$ each were constituted with a $5-\mathrm{cm}$ layer of soil, covered with a $2-\mathrm{cm}$ layer of water originating from each aforementioned site. One hundred young snails or 60 adults were then placed in each breeding box and the contents were allowed to dry by natural evaporation in a room subjected to diurnally fluctuating temperatures (from $6^{\circ} \mathrm{C}$ to $22^{\circ} \mathrm{C}$ ). An hourly surveillance was performed to determine the number of snails that buried in the drying soil and the conditions of this process (snail completely buried, or partial burrowing by $50 \%$ or $75 \%$ ). Six litres of water were finally poured in each breeding box to flood dried substratum and to re-activate buried snails.

\subsection{Parameters studied}

The alive $G$. truncatula were recognized from dead snails by the presence or the absence of a reaction after the pinch of a tentacle under the stereomicroscope.

The parameters studied in the first investigation were the numbers of $G$. truncatula noted during the first or the third count, the corresponding survival rates, and the shell height of surviving snails. In the second investigation, they were the numbers of live snails which left dried soil samples after their flooding with water, the height of their shells, and the durations of snail re-activation in water. Lastly, in the third investigation, the numbers of snails buried into the mud and the corresponding percentages were studied.

Individual values for the shell heights in the first investigation and for each parameter studied in the second investigation were averaged, and standard deviations were established, taking into account the parameter, the site studied, and the year of investigation. Comparison test of experimental frequencies and one-way analysis of variance (Stat-Itcf 1988) were used to establish levels of significance.

\section{Results}

Table 1 gives the results recorded in the 49 ditch areas during summer drying. In open drainage furrows as well as in road ditches, the survival rates of $G$. truncatula after flooding were significantly higher ( $P<0.01$ in each case) in the highland populations than in the lowland ones. Several differences $(P<0.05)$ could be noted between the rates of the highland populations or those of the lowland ones when snails were living in open drainage furrows. In contrast, in road ditches, there were no significant differences between the rates of the highland populations, those of the lowland ones,-or.between.1997. and 1998 for each site studied. The shell heights of surviving snails were slightly higher in the case of highland populations. However, the mean values did not show any significant variation, whatever the mode of comparison.

Table 2 gives the number of surviving snails, their shell height, and the duration of snail re-activation when samples of dried soil are placed in spring water. After activation in water, surviving snails were significantly more numerous $\left(\mathrm{F}_{5.26}=4.77, \mathrm{P}<0.01\right)$ in the highland populations of $G$. truncatula than in the others. The standard deviations of shell heights were greater in the former populations than in the latter ones but there were no significant differences between the mean values. The mean duration of snail re-activation in water ranged from 7.6 to 8.9 hours and did not show any significant variation. 
Table 1. Survival rates and shell heights of surviving snails after aestivation in the lowland and highland populations of $\mathrm{Gal}$ ba truncatula.

Tableau 1. Taux de survie et hauteur des coquilles des mollusques ayant survécu à l'estivation dans des populations de plaine et d'altitude de Galba truncatula.

\begin{tabular}{|c|c|c|c|c|c|c|c|}
\hline \multirow[t]{2}{*}{ Station } & \multirow{2}{*}{$\begin{array}{l}\text { Altitude } \\
\text { in } \mathrm{m}\end{array}$} & \multirow[t]{2}{*}{ Year } & \multirow{2}{*}{$\begin{array}{l}\text { Area } \\
\text { studied } \\
\text { in } \mathrm{m}^{2}\end{array}$} & \multicolumn{3}{|c|}{ Total number of live snails ${ }^{(1)}$} & \multirow{2}{*}{$\begin{array}{l}\text { Shell height of } \\
\text { surviving snails } \\
\text { in } \mathrm{mm}^{(3)}\end{array}$} \\
\hline & & & & $\begin{array}{l}\text { Count } \\
n^{\circ} 1\end{array}$ & $\begin{array}{l}\text { Count } \\
n^{\circ} 2\end{array}$ & $\begin{array}{l}\text { Count }^{\circ} 3 \\
\text { (and survival } \\
\text { rate }^{(2)} \text { in \%) }\end{array}$ & \\
\hline Open drainage & 206 & 1996 & 4 & 97 & 27 & $31(31.9)$ & $1.8 \pm 0.5$ \\
\hline furrows in & 227 & & 2 & 51 & 11 & $13(25.4)$ & $1.9 \pm 0.7$ \\
\hline \multirow[t]{2}{*}{ meadows } & 254 & & 2 & 42 & 15 & $17(35.7)$ & $2.0 \pm 0.6$ \\
\hline & 282 & & 2 & 48 & 9 & $11(22.9)$ & $1.8 \pm 0.6$ \\
\hline Road & 260 & 1997 & 10 & 285 & 152 & $90(31.5)$ & $1.9 \pm 0.6$ \\
\hline \multirow[t]{3}{*}{ ditches } & & 1998 & 10 & 252 & 191 & $74(29.3)$ & $1.8 \pm 0.7$ \\
\hline & 280 & 1997 & 10 & 211 & 115 & $62(29.3)$ & $2.1 \pm 0.8$ \\
\hline & & 1998 & 10 & 245 & 167 & $81(33.0)$ & $1.9 \pm 0.7$ \\
\hline Open drainage & 806 & 1996 & 4 & 106 & 11 & $67(63.2)$ & $3.2 \pm 0.9$ \\
\hline furrows in & 848 & & 2 & 47 & 5 & $37(78.7)$ & $2.9 \pm 0.8$ \\
\hline meadows & 871 & & 2 & 53 & 5 & $31(58.4)$ & $2.9 \pm 0.7$ \\
\hline Road & 820 & 1997 & 10 & 225 & 25 & $174(77.3)$ & $3.1 \pm 1.1$ \\
\hline \multirow[t]{3}{*}{ ditches } & & 1998 & 10 & 255 & 32 & $206(80.7)$ & $2.8 \pm 1.0$ \\
\hline & 900 & 1997 & 10 & 322 & 66 & $224(69.5)$ & $3.2 \pm 1.0$ \\
\hline & s. & 1998. & 10 & 281 & 75 & $202(71.8)$ & $3.0 \pm 0.9$ \\
\hline
\end{tabular}

(1). Count $n^{\circ}-1$ (performed at mid-June when each area was still covered with a $5 \mathrm{~cm}$ layer of water). Count $\mathrm{n}^{\circ} 2$ (made at the onset of July when the soil started to crack). Count $n^{\circ} 3$ (made two days after the flooding of each area with water).

(2). Survival rate : (count $\left.n^{\circ} 3\right) /\left(\right.$ count $\left.n^{\circ} 1\right)$

(3). Mean values $\pm S D$.

Table 3 gives the percentage of snails buried in the soil during an experimental drying of their breeding boxes under laboratory conditions $\left(20^{\circ} \mathrm{C}\right)$. The percentages of snails buried in the soil were higher in the highland population (13.0\% and $15.0 \%$ of juvenile snails, for example, instead of $4.0 \%$ and $7.7 \%$ in lowland snails). In the lowland population, only young snails buried, whereas $5.8 \%$ and $8.3 \%$ of adults in the highland population were also burrowing. Despite a meticulous examination of the soil surface with a stereomicroscope, juvenile snails could not be seen because they were completely buried. In contrast, partial burrowing of adult snails was observed, with a shell buried by $50 \%$ ( 3 snails) or $75 \%$ (14 snails). 
Table 2. Numbers of live Galba truncatula, shell heights, and durations of snail re-activation after the flooding of dried soil samples with water.

Tableau 2. Nombre de Galba truncatula en vie, hauteur des coquilles et durée de leur reprise d'activité après l'immersion d'échantillons de sol desséché dans l'eau.

\begin{tabular}{|c|c|c|c|c|c|c|}
\hline \multirow[t]{2}{*}{ Station } & \multirow{2}{*}{$\begin{array}{l}\text { Altitude } \\
\text { in } \mathrm{m}\end{array}$} & \multirow[t]{2}{*}{ Year } & \multirow{2}{*}{$\begin{array}{l}\text { Number } \\
\text { of } \\
\text { samples }\end{array}$} & \multicolumn{2}{|c|}{ Mean values $\pm S D$} & \multirow[b]{2}{*}{$\begin{array}{l}\text { Duration of snai } \\
\text { re-activation in } \\
\text { water (hours) }\end{array}$} \\
\hline & & & & $\begin{array}{l}\text { Number of live } \\
\text { snails per sample }\end{array}$ & $\begin{array}{l}\text { Shell height } \\
(\mathrm{mm})\end{array}$ & \\
\hline Open drainage & 227 & 1997 & 6 & $15.3 \pm 7.2$ & $1.6 \pm 0.5$ & $7.6 \pm 2.1$ \\
\hline $\begin{array}{l}\text { furrows in } \\
\text { meadows }\end{array}$ & 282 & & 6 & $12.5 \pm 9.7$ & $1.7 \pm 0.4$ & $8.0 \pm 1.9$ \\
\hline $\begin{array}{l}\text { Road } \\
\text { ditches }\end{array}$ & 280 & 1998 & 10 & $20.5 \pm 10.4$ & $1.6 \pm 0.4$ & $8.9 \pm 2.6$ \\
\hline Open drainage & 806 & 1997 & 6 & $36.3 \pm 14.1$ & $2.1 \pm 0.9$ & $8.2 \pm 1.8$ \\
\hline $\begin{array}{l}\text { furrows in } \\
\text { meadows }\end{array}$ & 871 & & 6 & $41.3 \pm 10.5$ & $1.9 \pm 1.0$ & $8.5 \pm 2.2$ \\
\hline $\begin{array}{l}\text { Road } \\
\text { ditches }\end{array}$ & 820 & 1998 & 8 & $47: 2 \pm 16.7^{(1)}$ & $1.7 \pm 0.7$ & $8.4 \pm 1.8$ \\
\hline
\end{tabular}

(1). The values only concerned 4 samples. As the 4 others placed in the same box, the figure was not taken into account for the calculation of this mean value.

\section{Discussion}

Even though snail investigations were performed on 11 populations of $G$. truncatula living in siliceous habitats and subjected to the same period of summer drought in 1996, 1997, and 1998, the results obtained could be due, not only to the altitude of sites studied, but also to other factors such as microclimate. Under these conditions, these findings might not for the moment be generalized to snail populations living in other countries, as snail aestivation is dependent on local climatic variations which occur in the habitats of G. truncatula.

The percentage of $G$. truncatula able to survive drought in the highland populations might by explained by two perhaps complementary hypotheses. As the local climatic conditions from the highland sites were different from those existing in the Haute-Vienne de- partment, with a higher annual rainfall and more relative humidity, the first assumption would be to admit a slower drying of these snail habitats in June-July than in lowland sites, permitting snails to burrow into the soil or to hide better in the deepest places of the habitat. The second hypothesis would be to consider the greater ability of these highland $G$. truncatula to burrow the soil. The low numbers of live snails removed from these highland sites after the second count (Table 1) indicated that numerous snails have buried into the soil before the total disappearance of stagnant water and suggested that the stimulus triggering snail burrowing might be changes happening in hydrochemistry when summer drought proceeded.

Snail burrowing in soil before aestivation was already noted by Bednarz (1960) in the field or by Moukrim \& Rondelaud (1992* during an experimental drying of snails under arid climate conditions. According to the- 
Table 3. Numbers Galba truncatula buried in the soil during an experimental drying of snail environment under laboratory conditions.

Tableau 3. Nombre de Galba truncatula enfouies dans le sol lors d'un assèchement expérimental de leur milieu de vie dans les conditions du laboratoire.

\begin{tabular}{|c|c|c|c|c|c|}
\hline \multirow{2}{*}{$\begin{array}{l}\text { Type of habitat } \\
\text { (altitude) }\end{array}$} & \multirow{2}{*}{$\begin{array}{l}\text { Stage of } \\
\text { life }^{(1)}\end{array}$} & \multirow{2}{*}{$\begin{array}{l}1998, \text { or } \\
1999\end{array}$} & \multicolumn{2}{|c|}{ Number of alive Galba truncatula } & \multirow[b]{2}{*}{$\begin{array}{l}\text { buried in } \\
\text { the soil } \\
(\text { and } \%)^{(2)}\end{array}$} \\
\hline & & & $\begin{array}{l}\text { at the onset } \\
\text { of experiment }\end{array}$ & $\begin{array}{l}\text { found with shell } \\
\text { aperture applied } \\
\text { to the mud surface }\end{array}$ & \\
\hline Road ditch & Young & 1998 & 200 & 187 & $13(7.7)$ \\
\hline \multirow[t]{3}{*}{$(280 \mathrm{~m})$} & snails & 1999 & 200 & 192 & $8(4.0)$ \\
\hline & Adults & 1998 & 120 & 120 & $0(-)$ \\
\hline & & 1999 & 120 & 120 & $0(-)$ \\
\hline Road ditch & Young & 1998 & 200 & 170 & $30(15.0)$ \\
\hline \multirow[t]{3}{*}{$(820 \mathrm{~m})$} & snails & 1999 & 200 & 167 & $26(13.0)$ \\
\hline & Adults & 1998 & 120 & 110 & $10(8.3)^{(3)}$ \\
\hline & & 1999 & 120 & 113 & $7(5.8)^{(3)}$ \\
\hline
\end{tabular}

(1). Young snails (1-2 mm in height). Adults (4 to $6 \mathrm{~mm}$ ).

(2). These snails were alive after the flooding of dried soil with water.

(3). Partial burrowing : 3 snails with shell buried by $50 \%, 14$ snails with shell buried by $75 \%$.

se last authors, $30 \%$ of adult snails were completely buried in the soil on day 4 following the beginning of experiment, while an incomplete burrowing was noted for $20 \%$ of other snails, with the apex of the shell still visible. The results reported in this note demonstrated that burrowing was more developed in the highland populations of $G$. truncatula than in the lowland snails. To explain this finding, the most valid hypothesis would be to consider snail burrowing as a physiologic response of these highland $G$. truncatula to summer drying. The percentages of buried snails in the third investigation (13.0-15.0\% of juvenile snails and 5.8-8.3\% of adults) could be related, in our opinion, to experimental conditions used in the laboratory and would probably be higher in the field. An argument to support this last hypothesis was the number of live snails which exited from soil samples after their collection in dried sites and flooding with water (Table 2).

\section{References}

Bednarz S. 1960. - On the biology and ecology of Galba truncatula Muill. and cercariae of Fasciola hepatica $\mathrm{L}$. in basin of the river Barycz. Acta Parasitol. Pol., 8 : 279-288.

De Massias E. 1995. - Contribution à l'étude des générations annuelles chez Lymnaea truncatula Müller (Mollusque), vecteur de Fasciola hepatica Linné (Trématode) en fonction de l'altitude des prairies. Thèse Doct. Méd. Vét., Lyon, $\mathrm{n}^{\circ} 20: 92 \mathrm{p}$.

De Massias E., Rondelaud D., Mage C. \& Gevrey J. 1996. - Lymnaea truncatula Müller : une seule génération annuelle dans les prairies d'estive du Jura et des Alpes. Bull. Soc. Fr. Parasitol., 14 : 54-61.

Goumghar M.D. 2000. - Recherches écologiques, éthologiques et parasitologiques sur des populations marocaines et françaises de Galba truncatula (Mollusca). Doctorat Thèse, Univ. de Fès, Maroc : $270 \mathrm{p}$.

Kendall S.B. 1949. - Bionomics of Limnaea truncatula and the parthenitae of Fasciola hepatica under drought conditions. J. Helminthol., 23 : 57-68.

Mehl S. 1932. - Die Lebensbedingungen der Leberegelschnecke (Galba truncatula Müller). Untersuchungen über Schale, Verbreitung, Lebensgeschichte, natürliche Feinde und Bekämpfungsmöglichkeiten. Arb. Bayer Landesanst Pflanzenbau Pfanzenschutz, 2 : $1-177$. 
Moukrim A. \& Rondelaud D. 1992. - Vertical spatial behaviour patterns of Lymnaea truncatula in relation with origin of snails, infection with Fasciola hepatica, and experimental environment. Ann. Parasitol. Hum. Comp., 67 : 174-179.

Peters B.G. 1938. - Habitats of Limnaea truncatula in England and Wales during dry seasons. J. Helminthol., $16: 213-260$.

Roberts E.W. 1950. - Studies on the life-cycle of Fasciola hepati$c a$ (Linnaeus) and of its snail host, Limnaea (Galba) truncatula Müller in the field and under controlled conditions. Ann. Trop. Med. Parasitol., $44: 187-206$.

Rondelaud D. \& Morel-Vareille C. 1975. - Distribution estivale et survie des Limnées tronquées, Lymnaea (Galba) truncatula Müller, saines ou infestées par Fasciola hepatica L. Ann. Parasitol. Hum. Comp., 50 : 603-616.
Smith G. 1981. - A three-year study of Lymnaea truncatula habitats, disease foci of fascioliasis. Br. Vet. J., $137: 398-410$.

STAT-ITCF. 1988. - Manuel d'utilisation. Institut technique des céréales et des fourrages, Service des études statistiques, Boigneville, France : 210 p.

Vareille-Morel C, Dreyfuss, G. \& Rondelaud D. 1999. - The characteristics of habitats colonized by three species of Lymnaea (Mollusca) in swampy meadows on acid soil : their interest for control of fasciolosis. Ann. Limnol., 35 : 173-178. 